\title{
MSH2 Gene Mutation
}

National Cancer Institute

\section{Source}

National Cancer Institute. MSH2 Gene Mutation. NCI Thesaurus. Code C128821.

A change in the nucleotide sequence of the MSH2 gene. 